\title{
Reactions of kynurenic acid with hypobromous acid and hypochlorous acid
}

\author{
Toshinori Suzuki,* Hiroyuki Morishita, and Kosumo Fukuhara \\ School of Pharmacy, Shujitsu University, 1-6-1 Nishigawara, Okayama 703-8516, Japan
}

(Received 14 April, 2020; Accepted 31 August, 2020; Published online 31 October, 2020)

\begin{abstract}
Kynurenic acid, a tryptophan metabolite, acts as antagonist or agonist of several receptors. Hypobromous acid $(\mathrm{HOBr})$ and hypochlorous acid $(\mathrm{HOCl})$ are generated by eosinophils and neutrophils. At inflammation sites, kynurenic acid may encounter $\mathrm{HOBr}$ and $\mathrm{HOCl}$ to generate products. When kynurenic acid was incubated with $\mathrm{HOBr}$ under neutral conditions, kynurenic acid generated a single product almost exclusively. This was identified as 3-bromokynurenic acid. Kynurenic acid reacted with $\mathrm{HOCl}$, generating two products. The major product was identified as 3-chlorokynurenic acid with its oxidative decarboxylation product, 3-chloro-4-hydroxy-2(1H)-quinolinone as a by-product. Free amino acids suppressed the reactions of kynurenic acid with $\mathrm{HOBr}$ and $\mathrm{HOCl}$. Taurine suppressed the $\mathrm{HOCl}$ reaction but not the $\mathrm{HOBr}$ reaction. An eosinophil peroxidase system containing $\mathrm{H}_{2} \mathrm{O}_{2}$, $\mathrm{NaCl}$, and $\mathrm{NaBr}$ reacted with kynurenic acid, generating 3bromokynurenic acid under mildly acidic conditions. Although a myeloperoxidase system containing $\mathrm{H}_{2} \mathrm{O}_{2}$ and $\mathrm{NaCl}$ reacted with kynurenic acid to generate 3-chlorokynurenic acid under mildly acidic conditions, the product was altered to 3-bromokynurenic acid by addition of $\mathrm{NaBr}$ to the system. These results suggest that 3-bromokynurenic acid and 3-chlorokynurenic acid may be generated from kynurenic acid at inflammation sites in humans, although their formation will be suppressed by coexistent amino acids.
\end{abstract}

Key Words: kynurenic acid, hypobromous acid, hypochlorous acid, myeloperoxidase, eosinophil peroxidase

$\mathrm{K}$ ynurenic acid (KYNA) is a tryptophan metabolite generated by enzymes along the kynurenine pathway. ${ }^{(1)} \mathrm{KYNA}$ is an agonist of G-protein coupled GPR35 receptor, which presents predominantly on immune cells and in the gastrointestinal tract. ${ }^{(2)}$ The serum level of KYNA was significantly elevated in patients with inflammatory bowel disease, compared to control subjects. ${ }^{(3)}$ Several reports suggest that KYNA may have a positive influence on a number of pathologies of the gastrointestinal tract. ${ }^{(4)}$ KYNA is also an antagonist of both the $N$-methyl-D-aspartate receptor and the $\alpha 7$ nicotinic acetylcholine receptor. ${ }^{(5,6)}$ The brain level of KYNA was elevated in patients with schizophrenia and bipolar disorder. ${ }^{(7,8)}$ KYNA possesses neuroprotective properties, since it blocks some of the neurotoxic effects of excitotoxins. ${ }^{(9)}$ Recently, the relationship between inflammation and these disorders has received. ${ }^{(10,11)}$ Eosinophils are a minor component of white blood cells, but are abundant in blood and tissues in various inflammatory disorders. ${ }^{(12)}$ Eosinophils discharge eosinophil peroxidase (EPO), which catalyzes the oxidation of bromide ion $\left(\mathrm{Br}^{-}\right)$to hypobromous acid ( $\mathrm{HOBr})$ through hydrogen peroxide $\left(\mathrm{H}_{2} \mathrm{O}_{2}\right)$ reduction. ${ }^{(13,14)}$ Although the plasma concentrations are $39-84 \mu \mathrm{M}$ for $\mathrm{Br}^{-}$and $100 \mathrm{mM}$ for $\mathrm{Cl}^{-}$, EPO uses $\mathrm{Br}^{-}$selectively, resulting in $\mathrm{HOBr}^{(15)}$ The formed $\mathrm{HOBr}$ plays an important role in defense mechanisms against parasites. Meanwhile, neutrophils discharge myeloperoxidase (MPO), which catalyzes the oxidation of chloride ion $\left(\mathrm{Cl}^{-}\right)$to hypochlorous acid $(\mathrm{HOCl})$ through hydrogen peroxide $\left(\mathrm{H}_{2} \mathrm{O}_{2}\right)$ reduction. ${ }^{(16-18)}$ Neutrophils are a major component of white blood cells. The $\mathrm{HOCl}$ formed by MPO plays a central role in host defense mechanisms against infection. Since $\mathrm{HOCl}$ can react with $\mathrm{Br}^{-}$to generate $\mathrm{HOBr}$, a portion of the $\mathrm{HOCl}$ formed by the MPO system will react with $\mathrm{Br}^{-}$of the plasma concentration converting to $\mathrm{HOBr} .^{(19,20)}$ Under inflammation conditions, KYNA may encounter $\mathrm{HOBr}$ and $\mathrm{HOCl}$, and react with them. However, there is little information about the reactions of KYNA with $\mathrm{HOBr}$ and $\mathrm{HOCl}$. In the present study, we examined the reactions of KYNA with reagents $\mathrm{HOBr}$ and $\mathrm{HOCl}$, and with peroxidases EPO and MPO, using RP-HPLC, and found that both the reagents and the peroxidase systems readily react with KYNA to generate halogenated products.

\section{Materials and Methods}

Materials. KYNA was purchased from ChemCruz (Dallas, TX). $\mathrm{NaBr}(>99.99 \%), \mathrm{NaCl}(>99.99 \%), \mathrm{KH}_{2} \mathrm{PO}_{4}, \mathrm{~K}_{2} \mathrm{HPO}_{4}, \mathrm{MPO}$ from human leukocytes, and EPO human recombinant protein were purchased from Sigma-Aldrich (St. Louis, MO). Other chemicals were obtained from Nacalai Tesque (Kyoto, Japan) or TCI (Tokyo). Bromide-free hypobromous acid (HOBr) was prepared by the addition of silver nitrate and subsequent distillation, as previously reported. ${ }^{(21)}$ The concentration of $\mathrm{HOBr}$ was determined spectrophotometrically at $331 \mathrm{~nm}$ in $10 \mathrm{mM} \mathrm{NaOH}$ using a molar extinction coefficient of $315 \mathrm{M}^{-1} \mathrm{~cm}^{-1}$. ${ }^{(22)}$ Chloridefree sodium hypochlorite $(\mathrm{NaOCl})$ was prepared by the method previously reported. ${ }^{(23)}$ The concentration of $\mathrm{NaOCl}$ was determined spectrophotometrically at $290 \mathrm{~nm}$ using a molar extinction coefficient of $350 \mathrm{M}^{-1} \mathrm{~cm}^{-1}$. (24)

HPLC and MS conditions. The HPLC system consisted of LC-10ADvp pumps and an SPD-M10Avp UV-vis photodiodearray detector (Shimadzu, Kyoto, Japan). For the RP-HPLC, an Inertsil ODS-3 octadecylsilane column of $4.6 \times 250 \mathrm{~mm}$ and particle size $5 \mu \mathrm{m}$ (GL Sciences, Tokyo, Japan) was used. The eluent was $20 \mathrm{mM}$ ammonium acetate (pH 7.0) containing acetonitrile. The acetonitrile concentration was increased from 0 to $14 \%$ during $40 \mathrm{~min}$ in linear gradient mode. The column temperature was $40^{\circ} \mathrm{C}$ and the flow rate was $1 \mathrm{ml} / \mathrm{min}$. The electrospray ionization time of flight mass spectrometry (ESITOF/MS) measurements were performed on a MicroTOF spectrometer (Bruker, Bremen, Germany) in negative mode.

Spectrometric data. Peak 1: 3-bromokynurenic acid (3-BrKYNA). ESI-TOF/MS: $m / z 222$ and 224 (1:1), 266 and 268 (1:1). HR-ESI-TOF/MS: 265.946532 obsd $(265.945829$ calcd for $\left.\mathrm{C}_{10} \mathrm{H}_{5} \mathrm{BrNO}_{3}^{-}\right)$. UV: $\lambda_{\max }=248,320,330 \mathrm{~nm} .{ }^{1} \mathrm{H} \mathrm{NMR}(500 \mathrm{MHz}$,

*To whom correspondance should be addressed.

E-mail: tsuzuki@shujitsu.ac.jp 
DMSO- $\left.d_{6}\right): \delta(\mathrm{ppm} / \mathrm{TMS}) 8.02(\mathrm{~d}, J=8.0 \mathrm{~Hz}, 1 \mathrm{H}), 7.61(\mathrm{~d}, J=$ $8.6 \mathrm{~Hz}, 1 \mathrm{H}), 7.55(\mathrm{dd}, J=7.7,7.7 \mathrm{~Hz}, 1 \mathrm{H}), 7.24(\mathrm{dd}, J=7.5$, $7.5 \mathrm{~Hz}, 1 \mathrm{H}),{ }^{13} \mathrm{C}$ NMR $\left(125 \mathrm{MHz}, \mathrm{DMSO}-d_{6}\right): \delta(\mathrm{ppm} / \mathrm{TMS})$ 171.7, 161.0, 151.0, 138.2, 131.0, 124.9, 123.0, 122.8, 118.3, 99.3.

Peak 2: 3-chlorokynurenic acid (3-Cl-KYNA). ESI-TOF/MS: $m / z 178$ and 180 (3:1), 222 and 224 (3:1). HR-ESI-TOF/MS: 221.996068 obsd $\left(221.996344\right.$ calcd for $\left.\mathrm{C}_{10} \mathrm{H}_{5} \mathrm{ClNO}_{3}^{-}\right)$. UV: $\lambda_{\max }=246,317,331 \mathrm{~nm} .{ }^{1} \mathrm{H}$ NMR $\left(500 \mathrm{MHz}\right.$, DMSO- $\left.d_{6}\right): \delta$ $(\mathrm{ppm} / \mathrm{TMS}) 8.06(\mathrm{~d}, J=8.0 \mathrm{~Hz}, 1 \mathrm{H}), 7.67(\mathrm{~d}, J=8.5 \mathrm{~Hz}, 1 \mathrm{H})$, $7.58(\mathrm{dd}, J=7.5,7.5 \mathrm{~Hz}, 1 \mathrm{H}), 7.27(\mathrm{dd}, J=7.5,7.6 \mathrm{~Hz}, 1 \mathrm{H}),{ }^{13} \mathrm{C}$ NMR (125 MHz, DMSO- $\left.d_{6}\right): \delta$ (ppm/TMS) 172.0, 162.0, 149.0, 138.2, 131.2, 124.8, 123.0, 122.8, 118.3, 109.0.

Peak 3: 3-chloro-4-hydroxy-2(1H)-quinolinone (3-Cl-HQN). ESI-TOF/MS: $m / z$ 158, 194 and 196 (3:1). HR-ESI-TOF/MS: 193.9996 obsd (194.0007 calcd for $\left.\mathrm{C}_{9} \mathrm{H}_{5} \mathrm{ClNO}_{2}{ }^{-}\right)$. UV: $\lambda_{\max }=218$, $300 \mathrm{~nm} .{ }^{1} \mathrm{H}$ NMR $\left(500 \mathrm{MHz}, \mathrm{DMSO}-d_{6}\right): \delta(\mathrm{ppm} / \mathrm{TMS}) 7.81$ $(\mathrm{d}, J=8.0 \mathrm{~Hz}, 1 \mathrm{H}), 7.21(\mathrm{dd}, J=7.5,7.6 \mathrm{~Hz}, 1 \mathrm{H}), 7.03(\mathrm{~d}, J=$ $8.5 \mathrm{~Hz}, 1 \mathrm{H}), 6.89$ (dd, $J=7.5,7.5 \mathrm{~Hz}, 1 \mathrm{H}),{ }^{13} \mathrm{C}$ NMR $(125 \mathrm{MHz}$, DMSO- $\left.d_{6}\right): \delta(\mathrm{ppm} / \mathrm{TMS}) 167.3,160.6,137.5,128.3,124.3$, 121.5, 118.9, 114.2, 99.6.

Quantitative procedures. The concentrations of the products were evaluated according to the integrated peak areas on RPHPLC chromatograms detected at $240 \mathrm{~nm}$ and by the molecular extinction coefficients at $240 \mathrm{~nm}\left(\varepsilon_{240 \mathrm{~nm}}\right)$. The $\varepsilon_{240 \mathrm{~nm}}$ value of $25,300 \mathrm{M}^{-1} \mathrm{~cm}^{-1}$ was used for KYNA. The $\varepsilon_{240 \mathrm{~nm}}$ values of Peaks 1-3 were determined from the integration of proton signals of NMR and the HPLC peak area detected at $240 \mathrm{~nm}$ relative to that of KYNA in the mixed solution. The estimated $\varepsilon_{240 \mathrm{~nm}}$ values were $27,300 \mathrm{M}^{-1} \mathrm{~cm}^{-1}$ for Peak $1,28,600 \mathrm{M}^{-1} \mathrm{~cm}^{-1}$ for Peak 2, and $22,700 \mathrm{M}^{-1} \mathrm{~cm}^{-1}$ for Peak 3 .

\section{Results}

Reaction with HOBr. A solution of $100 \mu \mathrm{M}$ KYNA was incubated with $100 \mu \mathrm{M} \mathrm{HOBr}$ in $100 \mathrm{mM}$ potassium phosphate buffer at $\mathrm{pH} 7.4$ and $37^{\circ} \mathrm{C}$ for $30 \mathrm{~min}$. When the reaction mixture was analyzed by reversed-phase (RP) HPLC, a product peak, Peak 1, appeared in the chromatogram detected at $240 \mathrm{~nm}$ (Fig. 1). The product was isolated by RP-HPLC and identified using MS and NMR $\left({ }^{1} \mathrm{H}-1 \mathrm{~d},{ }^{1} \mathrm{H}-{ }^{1} \mathrm{H}\right.$ COSY,${ }^{1} \mathrm{H}-{ }^{13} \mathrm{C}$ HMQC, ${ }^{1} \mathrm{H}-{ }^{13} \mathrm{C}$ HMBC, ${ }^{13} \mathrm{C}-$ 1d). Peak 1 showed an ESI-TOF/MS spectrum with $m / z=222$ and 224 (1:1) and 266 and 268 (1:1) in negative mode. High-resolution (HR) ESI-TOF/MS values of the molecular ion for Peak 1 agreed with the theoretical molecular mass for $\mathrm{C}_{10} \mathrm{H}_{5} \mathrm{BrNO}_{3}{ }^{-}$attributable to $[\mathrm{KYNA}+\mathrm{Br}-2 \mathrm{H}]^{-}$within $3 \mathrm{ppm}$. ${ }^{1} \mathrm{H}$ NMR showed four aromatic protons coupled with each other on the ${ }^{1} \mathrm{H}-{ }^{1} \mathrm{H}$ COSY spectrum. ${ }^{13} \mathrm{C}$ NMR showed nine aromatic carbons and a carbon attributable to a carboxy group. From these data, Peak 1 was identified as 3-bromokynurenic acid (3-Br-KYNA) (Scheme 1). Figure 2 shows the $\mathrm{HOBr}$ dose-dependence of the reaction of KYNA with $\mathrm{HOBr}$ when $100 \mu \mathrm{M}$ KYNA and $0-100 \mu \mathrm{M} \mathrm{HOBr}$ were incubated in $100 \mathrm{mM}$ potassium phosphate buffer at $\mathrm{pH} 7.4$ and $37^{\circ} \mathrm{C}$ for $30 \mathrm{~min}$. With increasing $\mathrm{HOBr}$ concentration, the consumptions of KYNA increased and the yield of 3-BrKYNA increased. KYNA was converted to 3-Br-KYNA almost exclusively.

Reaction with HOCl. A solution of $100 \mu \mathrm{M}$ KYNA was incubated with $100 \mu \mathrm{M} \mathrm{HOCl}$ in $100 \mathrm{mM}$ potassium phosphate buffer at $\mathrm{pH} 7.4$ and $37^{\circ} \mathrm{C}$ for $30 \mathrm{~min}$. When the reaction mixture was analyzed by RP-HPLC, two product peaks, Peaks 2 and 3, appeared in the chromatogram detected at $240 \mathrm{~nm}$ (Fig. 3). The products were isolated by RP-HPLC and identified. Peak 2 showed an ESI-TOF/MS spectrum with $m / z=178$ and $180(3: 1)$ and 222 and 224 (3:1) in negative mode. HR-ESI-TOF/MS values of the molecular ion for Peak 2 agreed with the theoretical molecular mass for $\mathrm{C}_{10} \mathrm{H}_{5} \mathrm{ClNO}_{3}{ }^{-}$attributable to $[\mathrm{KYNA}+\mathrm{Cl}-2 \mathrm{H}]^{-}$ within $3 \mathrm{ppm} .{ }^{1} \mathrm{H}$ NMR showed four aromatic protons correlated with each other on ${ }^{1} \mathrm{H}-{ }^{1} \mathrm{H}$ COSY.${ }^{13} \mathrm{C}$ NMR showed nine aromatic

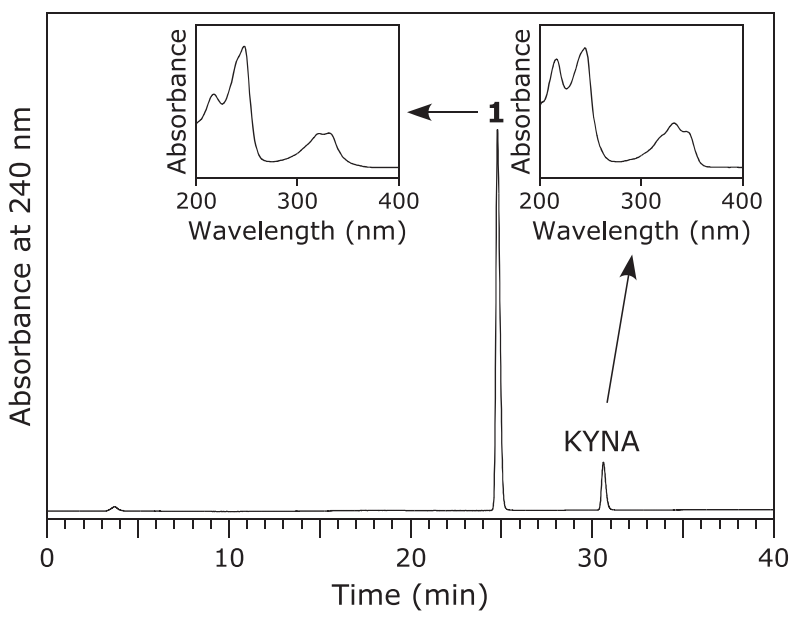

Fig. 1. RP-HPLC chromatogram of a reaction mixture of KYNA with $\mathrm{HOBr}$ detected at $240 \mathrm{~nm}$. A solution of $100 \mu \mathrm{M}$ KYNA was incubated with $100 \mu \mathrm{M} \mathrm{HOBr}$ in $100 \mathrm{mM}$ potassium phosphate buffer at $\mathrm{pH} 7.4$ and $37^{\circ} \mathrm{C}$ for $30 \mathrm{~min}$. The insets are the UV spectra of Peak 1 and KYNA.<smiles>O=C(O)c1cc(O)c2ccccc2n1</smiles>

Kynurenic acid (KYNA)

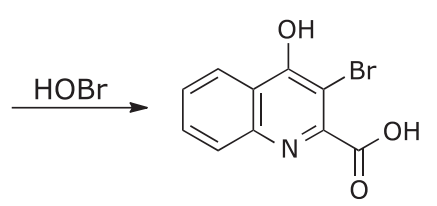

3-Bromokynurenic acid (3-Br-KYNA)
Scheme 1.

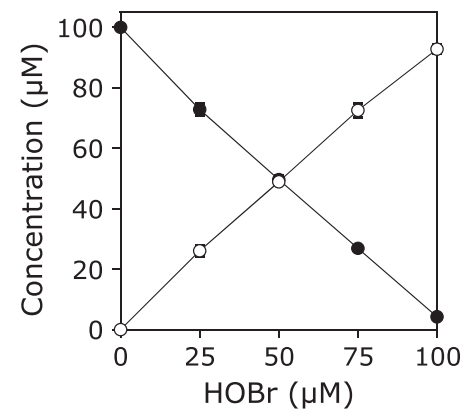

Fig. 2. HOBr dose-dependence of the concentration changes in KYNA and 3-Br-KYNA when a solution of $100 \mu \mathrm{M}$ KYNA was incubated with $0-100 \mu \mathrm{M} \mathrm{HOBr}$ in $100 \mathrm{mM}$ potassium phosphate buffer at $\mathrm{pH} 7.4$ and $37^{\circ} \mathrm{C}$ for $30 \mathrm{~min}$. KYNA (closed circle), 3-Br-KYNA (open circle). All the reaction mixtures were analyzed by RP-HPLC. Means \pm SD $(n=3)$ are presented.

carbons and a carbon attributable to a carboxy group. Peak 2 was identified as 3-chlorokynurenic acid (3-Cl-KYNA) (Scheme 2). Peak 3 showed an ESI-TOF/MS spectrum with $m / z=194$ and 196 (3:1) in negative mode. HR-ESI-TOF/MS values of the molecular ion for the Peak 3 agreed with the theoretical molecular mass for $\mathrm{C}_{9} \mathrm{H}_{5} \mathrm{ClNO}_{2}{ }^{-}$attributable to $[\mathrm{KYNA}+\mathrm{Cl}-\mathrm{CO}-2 \mathrm{H}]^{-}$within $3 \mathrm{ppm}$. ${ }^{1} \mathrm{H}$ NMR showed four aromatic protons correlated with each other on ${ }^{1} \mathrm{H}-{ }^{1} \mathrm{H}$ COSY. ${ }^{13} \mathrm{C}$ NMR showed nine aromatic carbons but no carbon of a carboxy group. Peak 3 was identified as 3-chloro-4-hydroxy-2(1H)-quinolinone (3-Cl-HQN) (Scheme 2). Figure 4 shows the $\mathrm{HOCl}$ dose-dependence of the reaction of 
<smiles>O=C(O)c1cc(O)c2ccccc2n1</smiles>

Kynurenic acid (KYNA)<smiles>O=C(O)c1nc2ccccc2c(O)c1Cl</smiles>

3-Chlorokynurenic acid 3-Chloro-4-hydroxy(3-Cl-KYNA)
$2(1 H)$-quinolinone (3-Cl-HQN)

Scheme 2.

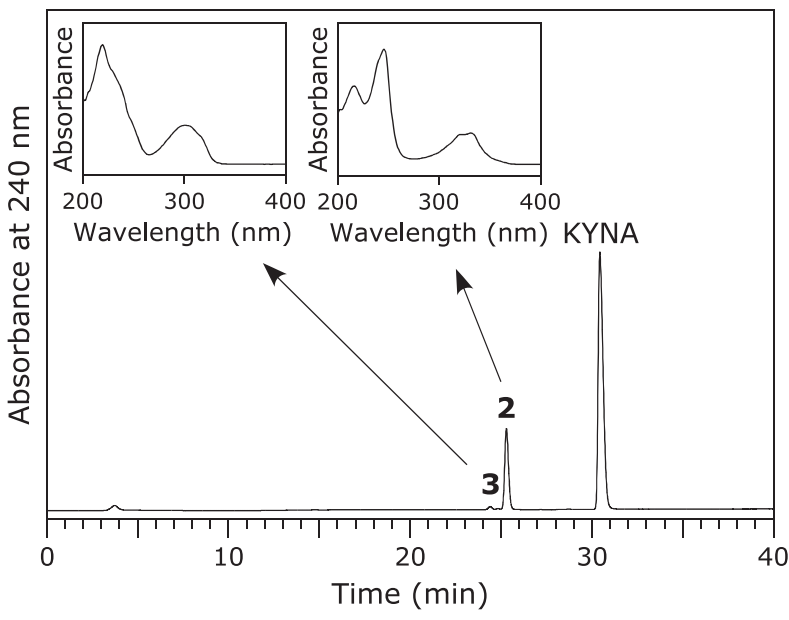

Fig. 3. RP-HPLC chromatogram of a reaction mixture of KYNA with $\mathrm{HOCl}$ detected at $240 \mathrm{~nm}$. A solution of $100 \mu \mathrm{M}$ KYNA was incubated with $100 \mu \mathrm{M} \mathrm{HOCl}$ in $100 \mathrm{mM}$ potassium phosphate buffer at $\mathrm{pH} 7.4$ and $37^{\circ} \mathrm{C}$ for $30 \mathrm{~min}$. The insets are the UV spectra of Peak 2 and Peak 3.

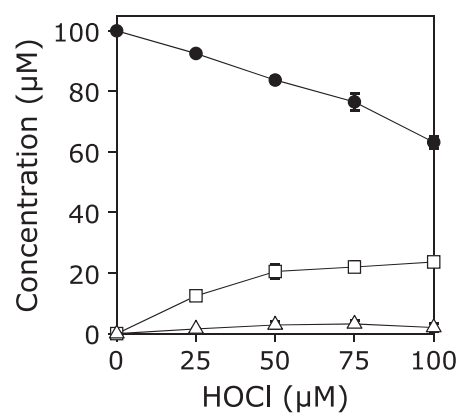

Fig. 4. $\mathrm{HOCl}$ dose-dependence of the concentration changes in KYNA and products, 3-Cl-HQN and 3-Cl-KYNA, when a solution of $100 \mu \mathrm{M}$ KYNA was incubated with $0-100 \mu \mathrm{M} \mathrm{HOCl}$ in $100 \mathrm{mM}$ potassium phosphate buffer at $\mathrm{pH} 7.4$ and $37^{\circ} \mathrm{C}$ for $30 \mathrm{~min}$. KYNA (closed circle), 3-ClKYNA (open square), and 3-Cl-HON (open triangle). All the reaction mixtures were analyzed by RP-HPLC. Means \pm SD $(n=3)$ are presented.

KYNA with $\mathrm{HOCl}$. With increasing $\mathrm{HOCl}$ concentration, the consumptions of KYNA and both the yields of 3-Cl-KYNA and 3-Cl-HQN increased. The reactivity of $\mathrm{HOCl}$ to KYNA was lower than that of HOBr. The yield of 3-Cl-KYNA was higher than that of 3-Cl-HQN.

Reaction with $\mathrm{HOCl}$ in the presence of $\mathrm{NaBr}$. A solution of $100 \mu \mathrm{M}$ KYNA was incubated with $100 \mu \mathrm{M} \mathrm{HOCl}$ in the presence of $0-100 \mu \mathrm{M} \mathrm{NaBr}$ in $100 \mathrm{mM}$ potassium phosphate buffer at $\mathrm{pH} 7.4$ and $37^{\circ} \mathrm{C}$ for $30 \mathrm{~min}$ (Fig. 5). Consumption of

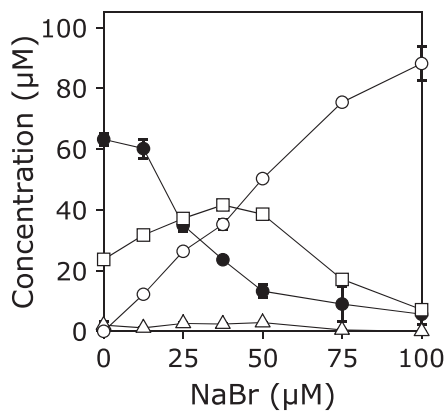

Fig. 5. $\mathrm{NaBr}$ dose-dependence of the concentration changes in KYNA and products in the reaction with $\mathrm{HOCl}$. A solution of $100 \mu \mathrm{M}$ KYNA was incubated with $100 \mu \mathrm{M} \mathrm{HOCl}$ in the presence of $0-100 \mu \mathrm{M} \mathrm{NaBr}$ in $100 \mathrm{mM}$ potassium phosphate buffer at $\mathrm{pH} 7.4$ and $37^{\circ} \mathrm{C}$ for $30 \mathrm{~min}$. KYNA (closed circle), 3-Br-KYNA (open circle), 3-Cl-KYNA (open square) and $3-\mathrm{Cl}-\mathrm{HQN}$ (open triangle). All the reaction mixtures were analyzed by RP-HPLC. Means \pm SD $(n=3)$ are presented.

Table 1. Effects of additives on the reactions of KYNA with $\mathrm{HOBr}^{\mathrm{a})}$

\begin{tabular}{lrc}
\hline Additives & KYNA $(\mu \mathrm{M})$ & 3-Br-KYNA $(\mu \mathrm{M})$ \\
\hline None & $4.0 \pm 0.2$ & $94.1 \pm 1.2$ \\
$\mathrm{NH}_{4} \mathrm{Cl}$ & $80.8 \pm 1.6$ & $22.4 \pm 1.4$ \\
$\mathrm{CH}_{3} \mathrm{NH}_{2} / \mathrm{HCl}$ & $1.2 \pm 1.7$ & $98.6 \pm 0.8$ \\
$\left(\mathrm{CH}_{3}\right)_{2} \mathrm{NH} / \mathrm{HCl}$ & $0.3 \pm 0.4$ & $97.9 \pm 1.0$ \\
$\left(\mathrm{CH}_{3}\right)_{3} \mathrm{~N} / \mathrm{HCl}$ & $0.0 \pm 0.0$ & $99.7 \pm 1.5$ \\
$\left(\mathrm{CH}_{3}\right)_{4} \mathrm{NCl}$ & $0.0 \pm 0.0$ & $97.8 \pm 1.7$ \\
$\mathrm{Gly}$ & $65.4 \pm 1.3$ & $32.1 \pm 1.0$ \\
Lys & $88.0 \pm 0.2$ & $9.2 \pm 0.1$ \\
Met & $93.4 \pm 0.6$ & $3.7 \pm 0.2$ \\
Cys & $93.1 \pm 1.1$ & $1.7 \pm 0.1$ \\
Taurine & $10.7 \pm 1.6$ & $86.8 \pm 0.6$ \\
Ascorbic acid & $72.7 \pm 0.1$ & $3.5 \pm 0.2$ \\
Urea & $9.6 \pm 2.5$ & $92.1 \pm 2.6$ \\
Glucose & $10.8 \pm 0.4$ & $90.2 \pm 2.0$ \\
CHCoONa & $1.9 \pm 2.3$ & $98.9 \pm 2.0$ \\
\hline
\end{tabular}

a) Concentrations of KYNA and 3-Br-KYNA when a solution of $100 \mu \mathrm{M}$ KYNA was incubated with $100 \mu \mathrm{M} \mathrm{HOBr}$ in $100 \mathrm{mM}$ potassium phosphate buffer $\left(\mathrm{pH} \mathrm{7.4)}\right.$ at $37^{\circ} \mathrm{C}$ for $24 \mathrm{~h}$ in the presence of the $1 \mathrm{mM}$ additives. All the reaction mixtures were analyzed by RP-HPLC. Means \pm SD $(n=3)$ are presented.

KYNA and the yield of 3-Br-KYNA increased with increasing $\mathrm{NaBr}$ dose. At $100 \mu \mathrm{M} \mathrm{NaBr}$, the major product was 3-Br-KYNA.

Effects of additives on the reaction with $\mathrm{HOBr}$. To obtain information about the effects of coexistent compounds on the reactions of KYNA with $\mathrm{HOBr}$, experiments were carried out in the presence of various additives. Table 1 shows the concentrations of KYNA and 3-Br-KYNA when a solution of $100 \mu \mathrm{M}$ KYNA and $1 \mathrm{mM}$ additives was incubated with $100 \mu \mathrm{M} \mathrm{HOBr}$ in $100 \mathrm{mM}$ potassium phosphate buffer $\left(\mathrm{pH} \mathrm{7.4)}\right.$ at $37^{\circ} \mathrm{C}$ for $24 \mathrm{~h}$. 
Although ammonium chloride suppressed the reaction, methylamine, dimethylamine, trimethylamine, and tetramethylammonium chloride had no effect. Amino acids suppressed the reaction. Taurine had no effect. Ascorbic acid suppressed the reaction. Urea, glucose, and sodium acetate had no effect.

Effects of additives on the reaction with $\mathrm{HOCl}$. To obtain information about the effects of coexistent compounds on the reactions of KYNA with $\mathrm{HOCl}$, experiments were carried out in the presence of various additives (Table 2). Ammonium chloride, methylamine, and dimethylamine strongly suppressed the reaction, while trimethylamine and tetramethylammonium chloride showed little effect. In the case of tetramethylammonium chloride, the yield of 3-Cl-HQN was comparable to that of 3-Cl-KYNA, probably due to facilitation of the decarboxylation of 3-Cl-KYNA by tetramethylammonium ion, generating 3-Cl-HQN. Amino acids and taurine suppressed the reaction almost completely. Ascorbic acid suppressed the formations of 3-Cl-KYNA and 3-Cl-HQN almost completely, although a certain amount of KYNA was consumed. Urea, glucose, and sodium acetate showed little effect.

Reaction of KYNA with EPO systems. Figure 6A and B show the $\mathrm{pH}$ dependence of concentrations of KYNA and the products in the reaction of KYNA with an $\mathrm{EPO} / \mathrm{H}_{2} \mathrm{O}_{2} / \mathrm{Cl}^{-}$system without or with $\mathrm{Br}^{-}$, respectively. A $100 \mu \mathrm{M}$ KYNA solution with $100 \mu \mathrm{M} \mathrm{H} \mathrm{H}_{2} \mathrm{O}_{2}, 100 \mathrm{mM} \mathrm{NaCl}$, and $0.2 \mathrm{unit} / \mathrm{ml} \mathrm{EPO}$ in $100 \mathrm{mM}$ potassium phosphate buffer $(\mathrm{pH} 2.8-9.6)$ in the absence or presence of $100 \mu \mathrm{M} \mathrm{NaBr}$ was incubated at $37^{\circ} \mathrm{C}$ for $30 \mathrm{~min}$, and the reaction was terminated by addition of $1 \mathrm{mM} \mathrm{N}$-acetylcysteine (AcCys). In the absence of $\mathrm{NaBr}$, the reactions were slow even under mildly acidic conditions. Small but comparable amounts of 3-Br-KYNA and 3-Cl-KYNA were generated. No reaction was observed above $\mathrm{pH}$ 7. In the presence of $100 \mu \mathrm{M} \mathrm{NaBr}$, KYNA was consumed and 3-Br-KYNA formed under mildly acidic conditions. The maximum consumption of KYNA was observed at $\mathrm{pH} 4-5$. At around $\mathrm{pH} 7$, the reaction was still observed. 3-ClKYNA and 3-Cl-HQN were not generated over the $\mathrm{pH}$ range examined.

Reaction of KYNA with MPO systems. Figure 7A and B show the $\mathrm{pH}$ dependence of concentrations of KYNA and the products in the reaction of KYNA with an $\mathrm{MPO} / \mathrm{H}_{2} \mathrm{O}_{2} / \mathrm{Cl}^{-}$system with or without $\mathrm{Br}^{-}$, respectively. In the absence of $\mathrm{NaBr}, 3-\mathrm{Cl}-$ KYNA was formed under mildly acidic conditions. Small amounts of 3-Br-KYNA were also generated, although 3-Cl-HQN was not detected. The maximum consumption of KYNA was observed at around $\mathrm{pH} 5$. No reaction was observed above $\mathrm{pH} 7$. In the presence of $100 \mu \mathrm{M} \mathrm{NaBr}, 3-\mathrm{Br}-\mathrm{KYNA}$ was formed under mildly acidic conditions. 3-Cl-KYNA and 3-Cl-HQN were not generated over the $\mathrm{pH}$ range examined. No reaction was observed above $\mathrm{pH} 7$.

Table 2. Effects of additives on the reactions of KYNA with $\mathrm{HOCl}^{\mathrm{a})}$

\begin{tabular}{llcc}
\hline Additives & KYNA $(\mu \mathrm{M})$ & 3-Cl-KYNA $(\mu \mathrm{M})$ & 3-Cl-HQN $(\mu \mathrm{M})$ \\
\hline None & $66.3 \pm 3.8$ & $19.5 \pm 0.5$ & $3.1 \pm 1.4$ \\
$\mathrm{NH}_{4} \mathrm{Cl}$ & $94.4 \pm 0.8$ & $0.5 \pm 0.1$ & $0.0 \pm 0.0$ \\
$\mathrm{CH}_{3} \mathrm{NH}_{2} / \mathrm{HCl}$ & $97.0 \pm 1.0$ & $0.6 \pm 0.2$ & $0.0 \pm 0.0$ \\
$\left(\mathrm{CH}_{3}\right)_{2} \mathrm{NH} / \mathrm{HCl}$ & $92.4 \pm 0.6$ & $2.4 \pm 0.2$ & $0.0 \pm 0.0$ \\
$\left(\mathrm{CH}_{3}\right)_{3} \mathrm{~N} / \mathrm{HCl}$ & $48.2 \pm 1.5$ & $21.7 \pm 0.4$ & $5.7 \pm 0.1$ \\
$\left(\mathrm{CH}_{3}\right)_{4} \mathrm{NCl}$ & $59.5 \pm 0.7$ & $12.1 \pm 0.1$ & $10.9 \pm 0.3$ \\
$\mathrm{Gly}$ & $98.1 \pm 0.4$ & $0.2 \pm 0.1$ & $0.0 \pm 0.0$ \\
Lys & $97.7 \pm 0.1$ & $0.2 \pm 0.2$ & $0.0 \pm 0.0$ \\
Met & $97.3 \pm 0.1$ & $0.5 \pm 0.1$ & $0.0 \pm 0.0$ \\
Cys & $98.6 \pm 1.2$ & $0.2 \pm 0.2$ & $0.0 \pm 0.0$ \\
Taurine & $96.0 \pm 3.0$ & $0.7 \pm 0.1$ & $0.0 \pm 0.0$ \\
Ascorbic acid & $74.7 \pm 0.1$ & $0.3 \pm 0.2$ & $0.0 \pm 0.0$ \\
Urea & $58.6 \pm 0.8$ & $26.6 \pm 0.7$ & $2.6 \pm 0.2$ \\
Glucose & $59.5 \pm 1.5$ & $21.6 \pm 0.4$ & $3.3 \pm 0.2$ \\
CH ${ }_{3}$ COONa & $59.0 \pm 2.7$ & $20.9 \pm 0.6$ & $3.8 \pm 0.5$ \\
\hline
\end{tabular}

a) Concentrations of KYNA, 3Cl-KYNA, and 3-Cl-HQN when a solution of $100 \mu \mathrm{M}$ KYNA was incubated with $100 \mu \mathrm{M} \mathrm{HOCl}$ in $100 \mathrm{mM}$ potassium phosphate buffer $(\mathrm{pH} 7.4)$ at $37^{\circ} \mathrm{C}$ for $24 \mathrm{~h}$ in the presence of the $1 \mathrm{mM}$ additives. All the reaction mixtures were analyzed by RP-HPLC. Means \pm SD $(n=3)$ are presented.
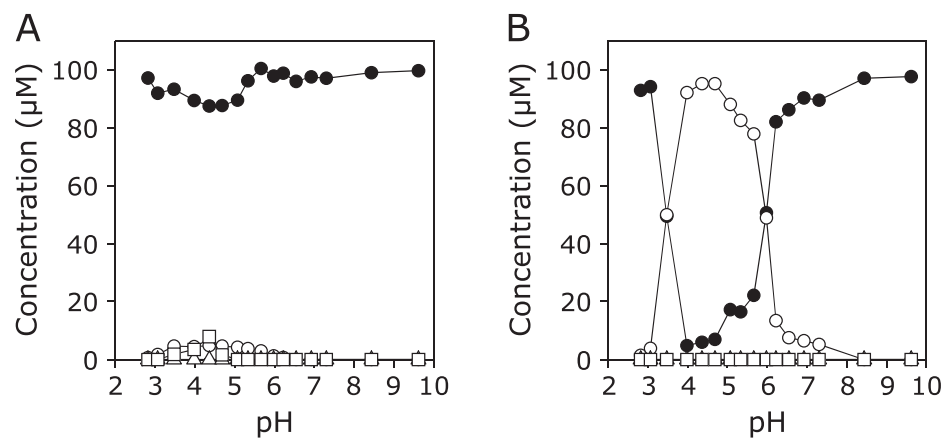

Fig. 6. (A) $\mathrm{pH}$ dependence of concentrations of $\mathrm{KYNA}$ and products in the reaction of $\mathrm{KYNA}$ with an $\mathrm{EPO} / \mathrm{H}_{2} \mathrm{O}_{2} / \mathrm{Cl}^{-}$system. $\mathrm{A} 100 \mu \mathrm{M} \mathrm{KYNA}$ solution with $100 \mu \mathrm{M} \mathrm{H}_{2} \mathrm{O}_{2}$ and $100 \mathrm{mM} \mathrm{NaCl}$ in the presence of 0.2 unit/ml EPO in $100 \mathrm{mM}$ potassium phosphate buffer (pH 2.8-9.6) was incubated at $37^{\circ} \mathrm{C}$ for $30 \mathrm{~min}$ and the reaction was terminated by addition of $1 \mathrm{mM}$ AcCys. (B) $\mathrm{pH}$ dependence of concentration of products in the reaction of $\mathrm{KYNA}$ with an EPO/ $\mathrm{H}_{2} \mathrm{O}_{2} / \mathrm{Cl}^{-}$system. A $100 \mu \mathrm{M}$ KYNA solution with $100 \mu \mathrm{M} \mathrm{H} \mathrm{H}_{2}, 100 \mathrm{mM} \mathrm{NaCl}$, and $100 \mu \mathrm{M} \mathrm{NaBr}$ in the presence of 0.2 unit/ml EPO in $100 \mathrm{mM}$ potassium phosphate buffer ( $\mathrm{pH}$ 2.8-9.6) was incubated at $37^{\circ} \mathrm{C}$ for $30 \mathrm{~min}$ and the reaction was terminated by addition of $1 \mathrm{mM}$ AcCys. $\mathrm{KYNA}$ (closed circle), 3-Br-KYNA (open circle), 3-Cl-KYNA (open square), and 3-Cl-HQN (open triangle). All the reaction mixtures were analyzed by RP-HPLC. 

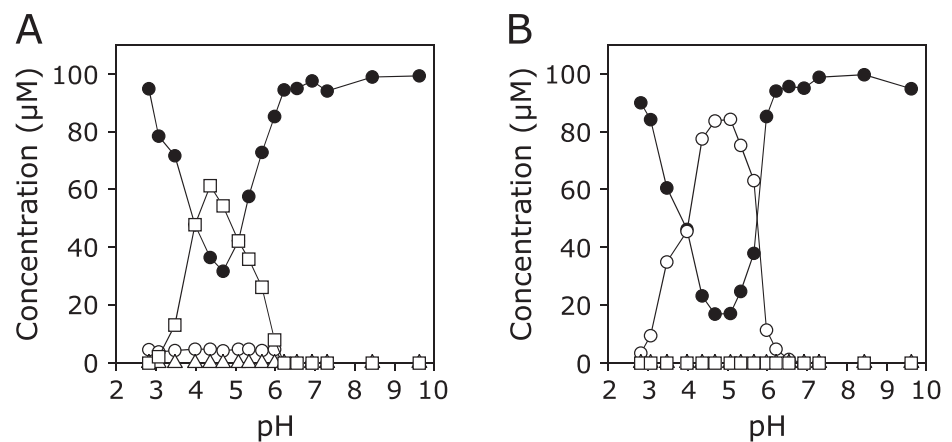

Fig. 7. (A) $\mathrm{pH}$ dependence of concentrations of KYNA and products in the reaction of KYNA with an MPO/ $\mathrm{H}_{2} \mathrm{O}_{2} / \mathrm{Cl}^{-}$system. A $100 \mu \mathrm{M} K Y N A$ solution with $100 \mu \mathrm{M} \mathrm{H}_{2} \mathrm{O}_{2}$ and $100 \mathrm{mM} \mathrm{NaCl}$ in the presence of $0.2 \mathrm{unit} / \mathrm{ml} \mathrm{MPO}$ in $100 \mathrm{mM}$ potassium phosphate buffer (pH 2.8-9.6) was incubated at $37^{\circ} \mathrm{C}$ for $30 \mathrm{~min}$ and the reaction was terminated by addition of $1 \mathrm{mM}$ AcCys. (B) pH dependence of concentration of products in the reaction of KYNA with an $\mathrm{MPO} / \mathrm{H}_{2} \mathrm{O}_{2} / \mathrm{Cl}^{-} / \mathrm{Br}^{-}$system. A $100 \mu \mathrm{M} \mathrm{KYNA}$ solution with $100 \mu \mathrm{M} \mathrm{H} \mathrm{O}_{2}, 100 \mathrm{mM} \mathrm{NaCl}$, and $100 \mu \mathrm{M} \mathrm{NaBr}$ in the presence of 0.2 unit/ml MPO in $100 \mathrm{mM}$ potassium phosphate buffer (pH 2.8-9.6) was incubated at $37^{\circ} \mathrm{C}$ for $30 \mathrm{~min}$ and the reaction was terminated by addition of $1 \mathrm{mM}$ AcCys. KYNA (closed circle), 3-Br-KYNA (open circle), 3-Cl-KYNA (open square), and 3-Cl-HQN (open triangle). All the reaction mixtures were analyzed by RP-HPLC.

\section{Discussion}

3-Br-KYNA and 3-Cl-KYNA were reportedly synthesized from an ethyl ester derivative of KYNA by treatment with $\mathrm{Br}_{2}$ and $\mathrm{SO}_{2} \mathrm{Cl}_{2}$, respectively, and subsequent hydrolysis. ${ }^{(25)}$ The present study showed that 3-Br-KYNA and 3-Cl-KYNA were generated directly as the major products of the reaction of KYNA with $\mathrm{HOBr}$ and $\mathrm{HOCl}$, respectively, under neutral conditions. We recently showed that rebamipide and methotrexate reacted with $\mathrm{HOBr}$, resulting in corresponding brominated products as major products. ${ }^{(26,27)}$ Methotrexate reacted with $\mathrm{HOCl}$ generating a corresponding chlorinated methotrexate, whereas rebamipide did not react with $\mathrm{HOCl}$. Like methotrexate, KYNA reacted with both $\mathrm{HOBr}$ and $\mathrm{HOCl}$. The reactivity of $\mathrm{HOBr}$ to KYNA was higher than that of $\mathrm{HOCl}$ (Fig. 2 and 4), probably due to the higher electrophilicity of $\mathrm{HOBr}$ compared to $\mathrm{HOCl}^{\left({ }^{(28)}\right.}$ In the presence of $\mathrm{NaBr}, \mathrm{HOCl}$ generated 3-Br-KYNA in addition to 3-Cl-KYNA, probably due to the formation of $\mathrm{HOBr}{ }^{(29)}$ At serum concentration of $\mathrm{Br}^{-}$(about $60 \mu \mathrm{M}$ ), the yield of 3-Br-KYNA was higher than that of 3-Cl-KYNA (Fig. 5). Amines had enhanced on the reactions of KYNA with $\mathrm{HOBr}$, whereas they suppressed the reactions with $\mathrm{HOCl}$ almost completely (Table 1 and 2 ). It has been reported that $\mathrm{CH}_{3} \mathrm{NH}_{2}$ and $\left(\mathrm{CH}_{3}\right)_{2} \mathrm{NH}$ react with $\mathrm{HOBr}$ and $\mathrm{HOCl}$ to generated corresponding bromamines and chloramines, respectively, and that second-order rate constants for the reactions of phenol with bromamines of $\mathrm{CH}_{3} \mathrm{NH}_{2}$ and $\left(\mathrm{CH}_{3}\right)_{2} \mathrm{NH}$ are several orders higher than those with chloramines. ${ }^{(30)}$ Similarly, KYNA would react strongly with bromamines of them to generate $3-\mathrm{Br}$ KYNA, whereas KYNA would not react with the chloramines. Free amino acids of $1 \mathrm{mM}$ suppressed the reactions of KYNA with both $\mathrm{HOBr}$ and $\mathrm{HOCl}$. For $\mathrm{HOCl}$, even Gly suppressed the reaction almost completely. Taurine suppressed the $\mathrm{HOCl}$ reaction but not the $\mathrm{HOBr}$ reaction. The reaction of KYNA in vivo with $\mathrm{HOBr}$ and especially $\mathrm{HOCl}$ should be suppressed by free amino acids and taurine, since the total concentration of free amino acids in human plasma is several $\mathrm{mM}$ and the concentration of taurine is high in neutrophils $(19 \mathrm{mM})$ and eosinophils $(15 \mathrm{mM}) .{ }^{(31,32)} \mathrm{An} \mathrm{EPO} / \mathrm{H}_{2} \mathrm{O}_{2} / \mathrm{Cl}^{-} / \mathrm{Br}^{-}$system reacted with KYNA, generating 3-Br-KYNA exclusively under mildly acidic conditions (Fig. 6B). Although an $\mathrm{MPO} / \mathrm{H}_{2} \mathrm{O}_{2} / \mathrm{Cl}^{-}$system reacted with KYNA to generate 3-Cl-KYNA under mildly acidic conditions with small amounts of 3-Br-KYNA (Fig. 7A), this was probably due to $\mathrm{Br}^{-}$as contaminant in $\mathrm{NaCl}$ or phosphate buffer. An MPO/ $\mathrm{H}_{2} \mathrm{O}_{2} / \mathrm{Cl}^{-} / \mathrm{Br}^{-}$system of $100 \mu \mathrm{M} \mathrm{NaBr}$ generated $3-\mathrm{Br}-\mathrm{KYNA}$ almost exclusively (Fig. 7B).

Several studies have reported the concentrations of halogenated derivatives of tyrosine (Tyr), 3-bromotyrosine (3-Br-Tyr) and 3chlorotyrosine (3-Cl-Tyr) in animals and humans, which were probably generated from Tyr by EPO and MPO. In wild-type mice, the concentration of free 3-Br-Tyr in the peritoneal fluid was comparable to that of free 3-Cl-Tyr. Treatment by cecal ligation and puncture greatly increased the concentrations of both $3-\mathrm{Br}-$ Tyr and 3-Cl-Tyr, with the average concentration of 3-Cl-Tyr three times higher than that of 3-Br-Tyr. ${ }^{(33)}$ In healthy volunteers, the concentration of 3-Cl-Tyr in proteins recovered from airways was five times higher than that of $3-\mathrm{Br}-\mathrm{Tyr}$, while in severe asthmatics the concentrations of both 3-Br-Tyr and 3-Cl-Tyr were higher than in healthy volunteers; the average concentration of 3-Br-Tyr was seven times higher than that of 3-Cl-Tyr. ${ }^{(34)}$ Another study showed that the concentration of free 3-Br-Tyr in human plasma of healthy male volunteers was three times higher than that of free 3-Cl-Tyr. ${ }^{(35)}$ In contrast, only one study reported the concentrations of halogenated nucleosides in humans. The concentration of 8-bromo-2'-deoxyguanosine (8-Br-dGuo) in urine from healthy volunteers was similar to that of 8-chloro-2'deoxyguanosine (8-Cl-dGuo), while urinary 8-Br-dGuo and 8-CldGuo levels from diabetic patients were 8-fold the levels in healthy volunteers. ${ }^{(36)}$ These reported results imply that both bromination and chlorination of living substances occur in healthy humans, and that inflammatory diseases greatly increase those levels. In humans, the concentration of KYNA is $0.003 \mu \mathrm{M}$ in saliva, $0.004-0.060 \mu \mathrm{M}$ in plasma, $0.14-1.58 \mu \mathrm{M}$ in brain, and $4-40 \mu \mathrm{M}$ in urine, whereas the concentration of Tyr ranges from 8 to $82 \mu \mathrm{M}$ (median $30 \mu \mathrm{M}$ ) in plasma and 7 to $366 \mu \mathrm{M}$ (median $64 \mu \mathrm{M})$ in urine. ${ }^{(4,37)}$ The halogenated derivatives of Tyr are detected in human plasma. ${ }^{(35)}$ The present study showed that in vitro EPO and MPO systems readily converted KYNA to its halogenated derivatives under mildly acidic conditions. There is a possibility that the halogenated derivatives of KYNA form in vivo, especially in urine, although the reaction rate constants of KYNA with $\mathrm{HOBr}$ and $\mathrm{HOCl}$ are not determined.

KYNA is an agonist of G-protein coupled GPR35 receptor, which presents predominantly on immune cells and in the gastrointestinal tract.(2) KYNA may have a positive influence on a number of pathologies of the gastrointestinal tract. ${ }^{(4)}$ KYNA is also an antagonist of both the $N$-methyl-D-aspartate receptor and the $\alpha 7$ nicotinic acetylcholine receptor. ${ }^{(5,6)}$ KYNA possesses neuroprotective properties, since it blocks some of the neurotoxic effects of excitotoxins. ${ }^{(9)}$ It has been reported that halogenated analogues of KYNA, such as 7-chlorokynurenic acid, 5,7dichlorokynurenic acid, and 5,7-dibromokynurenic acid, are selective antagonists at the glycine modulatory site of the $\mathrm{N}$ - 
methyl-D-aspartate receptor complex. ${ }^{(38,39)}$ However, the biological activities of 3-Br-KYNA and 3-Cl-KYNA have not been clarified. And also, the formations of 3-Br-KYNA and 3-Cl-KYNA are unclear in humans. If 3-Br-KYNA and 3-Cl-KYNA formed in body fluids and show biological activities, they may affect the pathophysiologies of various diseases with inflammation.

The present study showed that KYNA readily reacts with reagents of $\mathrm{HOBr}$ and $\mathrm{HOCl}$, and enzyme systems of $\mathrm{EPO}$ and

\section{References}

1 Badawy AA. Kynurenine pathway of tryptophan metabolism: regulatory and functional aspects. Int J Tryptophan Res 2017; 10: 1178646917691938.

2 Wang J, Simonavicius N, Wu X, et al. Kynurenic acid as a ligand for orphan G protein-coupled receptor GPR35. J Biol Chem 2006; 281: 22021-22028.

3 Forrest CM, Gould SR, Darlington LG, Stone TW. Levels of purine, kynurenine and lipid peroxidation products in patients with inflammatory bowel disease. Adv Exp Med Biol 2003; 527: 395-400.

4 Turski MP, Turska M, Paluszkiewicz P, Parada-Turska J, Oxenkrug GF. Kynurenic acid in the digestive system-new facts, new challenges. Int $J$ Tryptophan Res 2013; 6: 47-55.

5 Ganong AH, Cotman CW. Kynurenic acid and quinolinic acid act at $N$ methyl-D-aspartate receptors in the rat hippocampus. J Pharmacol Exp Ther 1986; 236: 293-299.

6 Hilmas C, Pereira EF, Alkondon M, Rassoulpour A, Schwarcz R, Albuquerque EX. The brain metabolite kynurenic acid inhibits alpha7 nicotinic receptor activity and increases non-alpha7 nicotinic receptor expression: physiopathological implications. J Neurosci 2001; 21: 7463-7473.

7 Erhardt S, Blennow K, Nordin C, Skogh E, Lindstrom LH, Engberg G. Kynurenic acid levels are elevated in the cerebrospinal fluid of patients with schizophrenia. Neurosci Lett 2001; 313: 96-98.

8 Olsson SK, Samuelsson M, Saetre P, et al. Elevated levels of kynurenic acid in the cerebrospinal fluid of patients with bipolar disorder. J Psychiatry Neurosci 2010; 35: 195-199.

9 Zinger A, Barcia C, Herrero MT, Guillemin GJ. The involvement of neuroinflammation and kynurenine pathway in Parkinson's disease. Parkinsons Dis 2011; 2011: 716859.

10 Müller N, Weidinger E, Leitner B, Schwarz MJ. The role of inflammation in schizophrenia. Front Neurosci 2015; 9: 372.

11 Fries GR, Walss-Bass C, Bauer ME, Teixeira AL. Revisiting inflammation in bipolar disorder. Pharmacol Biochem Behav 2019; 177: 12-19.

12 Rothenberg ME. Eosinophilia. N Engl J Med 1998; 338: 1592-1600.

13 Wang J, Slungaard A. Role of eosinophil peroxidase in host defense and disease pathology. Arch Biochem Biophys 2006; 445: 256-260.

14 Weiss SJ, Test ST, Eckmann CM, Roos D, Regiani S. Brominating oxidants generated by human eosinophils. Science 1986; 234: 200-203.

15 Holzbecher J, Ryan DE. The rapid determination of total bromine and iodine in biological fluids by neutron activation. Clin Biochem 1980; 13: 277-278.

16 Klebanoff SJ, Kettle AJ, Rosen H, Winterbourn CC, Nauseef WM. Myeloperoxidase: a front-line defender against phagocytosed microorganisms. J Leukoc Biol 2013; 93: 185-198.

17 Schultz J, Kaminker K. Myeloperoxidase of the leucocyte of normal human blood. I. Content and localization. Arch Biochem Biophys 1962; 96: 465-467.

18 Kettle AJ, Winterbourn CC. Myeloperoxidase: a key regulator of neutrophil oxidant production. Redox Rep 1997; 3: 3-15.

19 Thomas EL, Bozeman PM, Jefferson MM, King CC. Oxidation of bromide by the human leukocyte enzymes myeloperoxidase and eosinophil peroxidase. Formation of bromamines. J Biol Chem 1995; 270: 2906-2913.

20 Henderson JP, Byun J, Williams MV, Mueller DM, McCormick ML, Heinecke JW. Production of brominating intermediates by myeloperoxidase. A transhalogenation pathway for generating mutagenic nucleobases during inflammation. J Biol Chem 2001; 276: 7867-7875.

21 Rosowsky A, Wright JE, Holden SA, Waxman DJ. Influence of lipophilicity and carboxyl group content on the rate of hydroxylation of methotrexate derivatives by aldehyde oxidase. Biochem Pharmacol 1990; 40: 851-857.

22 Wajon JE, Morris JC. Rates of formation of $N$-bromo amines in aqueous solution. Inorg Chem 1982; 21: 4258-4263.
MPO, resulting in halogenated products in vitro. These results suggest that 3-Br-KYNA and 3-Cl-KYNA may be generated from KYNA by EPO and MPO in inflammation sites in humans.

\section{Conflict of Interest}

No potential conflicts of interest were disclosed.

23 Hazen SL, Hsu FF, Gaut JP, Crowley JR, Heinecke JW. Modification of proteins and lipids by myeloperoxidase. Methods Enzymol 1999; 300: 88105.

24 Morris JC. The acid ionization constant of $\mathrm{HOCl}$ from 5 to $35^{\circ} . J$ Phys Chem 1966; 70: 3798-3805

25 Surrey AR, Cutler RA. The preparation of 3-halo-4-dialkylaminoalkylaminoquinoline derivatives. J Am Chem Soc 1946; 68: 2570-2574.

26 Suzuki T, Okuyama A. Reactions of rebamipide with hypobromous acid. Chem Pharm Bull 2019; 67: 1164-1167.

27 Suzuki T, Takeuchi R. Reactions of methotrexate with hypobromous acid and hypochlorous acid. Chem Pharm Bull 2019; 67: 1250-1254.

28 Heeb MB, Criquet J, Zimmermann-Steffens SG, von Gunten U. Oxidative treatment of bromide-containing waters: formation of bromine and its reactions with inorganic and organic compounds - a critical review. Water Res 2014; 48: 15-42.

29 Thomas EL, Bozeman PM, Jefferson MM, King CC. Oxidation of bromide by the human leukocyte enzymes myeloperoxidase and eosinophil peroxidase. Formation of bromamines. J Biol Chem 1995; 270: 2906-2913.

30 Heeb MB, Kristiana I, Trogolo D, Arey JS, von Gunten U. Formation and reactivity of inorganic and organic chloramines and bromamines during oxidative water treatment. Water Res 2017; 110: 91-101.

31 Yamamoto H, Kondo K, Tanaka T, et al. Reference intervals for plasma-free amino acid in a Japanese population. Ann Clin Biochem 2016; 53 (Pt 3): 357 364.

32 Learn DB, Fried VA, Thomas EL. Taurine and hypotaurine content of human leukocytes. J Leukoc Biol 1990; 48: 174-182.

33 Gaut JP, Yeh GC, Tran HD, et al. Neutrophils employ the myeloperoxidase system to generate antimicrobial brominating and chlorinating oxidants during sepsis. Proc Natl Acad Sci USA 2001; 89: 11961-11966.

34 MacPherson JC, Comhair SA, Erzurum SC, et al. Eosinophils are a major source of nitric oxide-derived oxidants in severe asthma: characterization of pathways available to eosinophils for generating reactive nitrogen species. $J$ Immunol 2001; 166: 5763-5772.

35 Gaut JP, Byun J, Tran HD, Heinecke JW. Artifact-free quantification of free 3-chlorotyrosine, 3-bromotyrosine, and 3-nitrotyrosine in human plasma by electron capture-negative chemical ionization gas chromatography mass spectrometry and liquid chromatography-electrospray ionization tandem mass spectrometry. Anal Biochem 2002; 300: 252-259.

36 Asahi T, Kondo H, Masuda M, et al. Chemical and immunochemical detection of 8-halogenated deoxyguanosines at early stage inflammation. $J$ Biol Chem 2010; 285: 9282-9291.

37 Anesi A, Rubert J, Oluwagbemigun K, et al. Metabolic profiling of human plasma and urine, targeting tryptophan, tyrosine and branched chain amino acid pathways. Metabolites 2019; 9: 261.

38 Kemp JA, Foster AC, Leeson PD, et al. 7-Chlorokynurenic acid is a selective antagonist at the glycine modulatory site of the $N$-methyl-D-aspartate receptor complex. Proc Natl Acad Sci USA 1988; 85: 6547-6550.

39 Foster AC, Kemp JA, Leeson PD, et al. Kynurenic acid analogues with improved affinity and selectivity for the glycine site on the $N$-methyl-Daspartate receptor from rat brain. Mol Pharmacol 1992; 41: 914-922.

This is an open access article distributed under the terms of the Creative Commons Attribution-NonCommercial-NoDerivatives License (http://creativecommons.org/licenses/by-nc-nd/4.0/). 